Greece \& Rome, 68.1 61-75 (C) The Author(s), 2021. Published by Cambridge University Press on behalf of The Classical Association. This is an Open Access article, distributed under the terms of the Creative Commons Attribution licence (http://creativecommons.org/licenses/by/4.0/), which permits unrestricted re-use, distribution, and reproduction in any medium, provided the original work is properly cited.

doi:10.1017/S0017383520000248

\title{
THE EMOTIONS OF MEDEA THE LETTER-WRITER (OVID, HEROIDES 12)*
}

Medea fascinated Ovid more than any other female mythical figure. She features in the Ars Amatoria $(1.336 ; 2.381-2)$, the Heroides (6.75, $127-8,151 ; 12$ passim; 17.229, 233), the Metamorphoses (7.1-424), and the Tristia (3.9). Ovid also composed a tragedy called Medea (Am. 2.18.13-16; Tr. 2.553-4), which unfortunately has not survived. ${ }^{1}$ In the Remedia amoris Medea is mentioned in a list of mythical men and women who would have been cured of their torturing love passion, if Ovid had been their praeceptor. Medea is not named, but the identification is obvious (Rem. am. 59-60): nec dolor armasset contra sua viscera matrem, / quae socii damno sanguinis ulta virum est ('Nor would a mother's vengeance on her husband / have steeled her heart to slay their progeny'). ${ }^{2}$

* This article was originally presented at 'The Emotions of Medea' colloquium held at the Fondation Hardt (Vandœuvres, Geneva, 3-4 May 2019). I owe special thanks to the organizers, Damien Nelis and Douglas Cairns, for their kind invitation to participate in the colloquium. Unless otherwise indicated, all translations are my own.

${ }^{1}$ See Tac. Dial. 12; Quint. 10.1.98. On Ovid's Medea, see F. Della Corte, 'La Medea di Ovidio', SCO 19-20 (1970-71), 85-9; A. G. Nikolaidis, 'Some Observations on Ovid's Lost Medea', Latomus 44 (1985), 383-7; S. Hinds, 'Medea in Ovid: Scenes from the Life of an Intertextual Heroine', MD 30 (1993), 34-46; F. Bessone (ed.), P. Ovidii Nasonis Heroidum epistula XII Medea Iasoni (Florence, 1997), 14-19; T. Heinze, Der XII. Heroidenbrief. Medea an Fason. Einleitung, Text und Kommentar mit einer Beilage. Die Fragmente der Tragödie Medea (Leiden and New York, 1997), 21-4. On the relationship of this tragedy to Medea's letter (Her. 12) see F. Spoth, Ovids Heroides als Elegien (Munich, 1992), 198-205. See Hinds (this n.), 34-43, for Her. 12 as containing Ovid's Medea in palimpsest.

2 Translation from A. D. Melville (trans.), Ovid. The Love Poems (Oxford, 2008). For an overview of the Jason-Medea story in the Ovidian corpus see Heinze (n. 1), 13-19; A. Arcellaschi, Médée dans le théâtre latin d'Ennius à Sénèque (Rome, 1990), 231-47; S. A. Cecchin, 'Medea in Ovidio fra elegia ed epos', in R. Uglione (ed.), Atti delle giornate di studio su Medea, Torino 2324 Ottobre 1995 (Turin, 1997), 69-89; C. E. Newlands, 'The Metamorphosis of Ovid's Medea', in J. J. Clauss and S. I. Johnston (eds.), Medea. Essays on Medea in Myth, Literature, Philosophy, and Art (Princeton, NJ, 1997), 178-208. Nikolaidis (n. 1) mainly focuses on Heroides 12 and Metamorphoses 7, but also discusses Medea's role in other Ovidian passages. On Medea in Greek mythology and literature before Euripides, see P. Giannini, 'Medea nell'epica e nella poesia lirica arcaica e tardo-arcaica', in B. Gentili and F. Perusino (eds.), Medea nella letteratura e nell'arte 
In this article I intend to explore the emotions of Medea in her Ovidian letter to Jason (Her. 12). ${ }^{3}$ Medea is writing her letter while in Corinth, after her abandonment by Jason and his marriage to Creusa, but before the killing of her children. She finds herself in the same place as Hypsipyle, the queen of Lemnos, with whom Jason had an affair en route to Colchis (Ap. Rhod. Arg. 1). Hypsipyle, too, sends a letter to Jason (Her. 6). Although letters 6 and 12 share the same recipient and apparently are meant to converse implicitly with one another, Ovid's Medea does not seem to be aware of Jason's past with Hypsipyle. ${ }^{4}$

Epistolography as a genre is particularly suitable for the expression of personal thoughts and emotions. The letter-writer is offered the possibility for a more personal, sometimes alternative, narrative, often blurring the lines between 'real' and 'imaginary'. Every time someone writes a letter, in effect they build their own self. ${ }^{5}$ Depending on the circumstance and the specific needs, letter-writers select those parts of

(Venice, 2000), 13-27. More general studies on Medea include L. Belloni, 'Medea

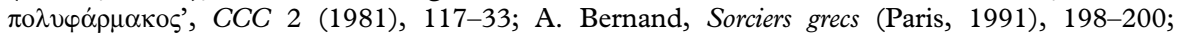
Clauss and Johnston (this n.); W. Fauth, Carmen magicum. Das Thema der Magie in der Dichtung der römischen Kaiserzeit (Frankfurt am Main, 1999), 103-20; Gentili and Perusino (this n.); E. Hall, F. Macintosh, and O. Taplin, Medea in Performance 1500-2000 (Oxford, 2000); A. Moreau and J.-C. Turpin (eds.), La magie, 4 vols. (Montpellier, 2000), ii.245-333; D. J. Mastronarde (ed.), Euripides. Medea (Cambridge, 2002), 44-57; D. Ogden, Magic, Witchcraft, and Ghosts in the Greek and Roman Worlds. A Sourcebook (New York, 2002), ch. 5; H. Bartel and A. Simon (eds.), Unbinding Medea. Interdisciplinary Approaches to a Classical Myth from Antiquity to the 21st Century (London, 2010); E. Griffiths, Medea (London and New York, 2006).

${ }^{3}$ The Ovidian authorship of Medea's letter has been challenged by R. J. Tarrant, 'The Authenticity of the Letter of Sappho to Phaon (Heroides 15)', HSPh 85 (1981), 152 n. 39; and mainly by P. Knox, 'Ovid's Medea and the Authenticity of Heroides 12', HSPh 90 (1986), 20723 , especially on the grounds of 'unOvidian' style and diction and the claim that lines 12.121-4 seem to borrow from Metamorphoses 7.62-5. Hinds (n. 1), 27-9; and T. Heinze, 'The Authenticity of Ovid Heroides 12 Reconsidered', BICS 38 (1991-3), 94-7, have convincingly countered Knox's and Tarrant's case and shown that Her. 12 is not genetically dependent on Met. 7 and is not unOvidian in style and in level of competence.

${ }^{4}$ On the relation between Her. 6 and 12, see Hinds (n. 1), 27-34; A. N. Michalopoulos, 'Fighting against a Witch: The Importance of Magic in Hypsipyle's Letter to Jason (Ov. Her. 6)', MHNH: Revista Internacional de Investigación sobre Magia y Astrología Antiguas 4 (2004), 97-122; V. Vaiopoulos, 'In-Between Lament and Irony: Some Cross-References in Ovid's Her. 6 and 12', Mediterranean Studies 21.2 (2013), 122-48.

${ }^{5}$ See P. A. Rosenmeyer, Ancient Epistolary Fictions. The Letter in Greek Literature (Cambridge, 2001), 11; M. Trapp, Greek and Latin Letters. An Anthology with Translation (Cambridge, 2003), 4. Contrast the ancient understanding about the ability of the letter to reflect authentically and dir-

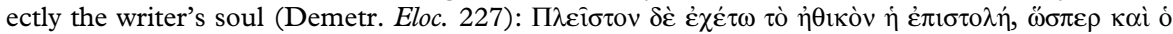

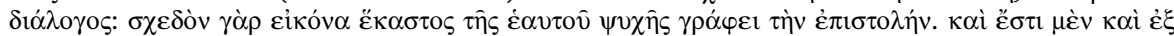

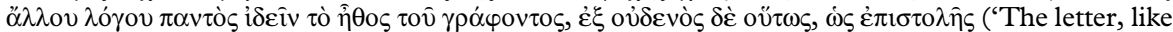
the dialogue, should abound in glimpses of character. It may be said that everybody reveals his own soul in his letters. In every other form of composition it is possible to discern the writer's character, 
reality that best serve their purpose. They select what, when, and how to write something, as well as what not to write. Through complex processes of selection, censorship, and self-censorship, letter-writers construct a version of reality, a 'textual' reality, which may resemble, coincide with, or even deviate significantly from objective reality.

The female letter-writers in the Heroides, including Medea, are no exception to this pattern; they record their own version of reality, which may not always be consistent with 'objective' reality. Any deviations may be the result of either deliberate misinterpretation or inability to understand reality. In this context of extreme subjectivity, the role of memory is dominant. ${ }^{6}$ The female letter-writers of the Heroides, displaced on the margins of life, of writing, and of love, trigger mnemonic mechanisms to reclaim their presence in the lives of their loved ones who have abandoned them. Memory fills and heals the void of absence and desertion. The past and its lost happiness becomes a final, if not unique refuge for them from their present misery. Through writing the women of the Heroides revive the past by reshaping it in the way they want or in the way their troubled minds allow them to. As a result, the boundaries between the real and the non-real collapse, whether deliberately or not.

Ovid places the letter of his Medea at a pivotal point in her mythical career. ${ }^{7}$ Medea outlines her past history and her present distress. She complains to Jason about his betrayal and her abandonment, she reminds him of her good services to him which he has forgotten, she invites him to return to her, and in the end she insinuates that she has already conceived a plan for revenge. Thus, the letter of this Ovidian Medea summarizes past events and prepares the ground for what is to follow. This is achieved through constant flashbacks and covert prefigurations of the future, so that the letter eventually contains, either fully narrated or in the form of hints, almost the whole of Medea's life. ${ }^{8}$

but in none so clearly as in the epistolary'). Translation from R. Roberts (ed. and trans.), Demetrius. On Style (Cambridge, 1902).

${ }^{6}$ On memory in the Heroides, see H. Jacobson, Ovid's Heroides (Princeton, NJ, 1974), 350-2, 358-60.

${ }^{7}$ P. J. Davis, “"A simple girl”? Medea in Ovid Heroides 12', Ramus 41 (2012), 33: 'Ovid has positioned his elegiac heroine between past and future, guilt and innocence, epic and tragedy.'

${ }^{8}$ In similar manner, Apollonius' Argonautica Book 3 simultaneously recalls Euripides' Medea a text prior to Apollonius' which, however, relates events from the life of Medea after Colchis - and foreshadows it. See R. L. Hunter (ed.), Apollonius of Rhodes. Argonautica Book 3 (Cambridge, 1989); Hinds (n. 1), 17. 
To design the character of his Medea, Ovid draws mainly from Apollonius' Argonautica, Euripides' Medea, and Ennius' Medea exul. ${ }^{9}$ The verb memini used by Medea right at the beginning of her letter (12.1-2) - At tibi Colchorum, memini, regina vacavi, / ars mea cum peteres ut tibi ferret opem ('But (I remember) though a princess of Colchis, I found time for you when you asked me to help with my magic'10) refers both to her memory as a literary character and, on a metapoetic level, to Ovid's memory as the external letter-writer, who draws on earlier works that span a wide range of poetic genres and time periods. ${ }^{11}$

Medea's letter to Jason is fraught with emotion from beginning to end. Looking at it from the point of view of emotions sheds light on her train of thought, enhances our understanding of this text, helps us to comprehend the motivation for her actions, and gives a more accurate depiction of the mythical figure of Medea as she is shaped by Ovid. ${ }^{12}$ The study of her emotions gives us the opportunity to grasp and appreciate her gradual transition from innocent young girl to fratricidal woman and then to jealous and betrayed woman who feels anger and rage for having been abandoned by the man she loved and supported through all the hardships and dangers they went through. This woman is soon expected not in the course of this letter but in a dramatic time covered by Euripides' Medea - to enact a terrible revenge and commit infanticide.

\footnotetext{
${ }^{9}$ For Medea in Republican tragedy (Accius' Medea siue Argonautae, Ennius' Medea Exul, Pacuvius' Medus), see Arcellaschi (n. 2), chs. 2-4; R. Cowan, 'A Stranger in a Strange Land: Medea in Roman Republican Tragedy', in H. Bartel and A. Simon (eds.), Unbinding Medea. Interdisciplinary Approaches to a Classical Myth from Antiquity to the 21st Century (London, 2010), 39-52.

${ }^{10}$ All Heroides translations are from P. Murgatroyd, B. Reeves, and S. Parker, Ovid's Heroides. A New Translation and Critical Essays (Abingdon and New York, 2017).

${ }^{11}$ See Bessone (n. 1), 63.

${ }_{12}$ Over the last few decades, important works on ancient Greek and Roman emotions have appeared. See among others D. Cairns, Aidos. The Psychology and Ethics of Honour and Shame in Ancient Greek Literature (Oxford, 1993); S. M. Braund and C. Gill (eds.), The Passions in Roman Thought and Literature (Cambridge, 1997); R. A. Kaster, Emotion, Restraint, and Community in Ancient Rome (New York, 2005); D. Konstan, The Emotions of the Ancient Greeks. Studies in Aristotle and Classical Literature (Toronto, 2006); D. Cairns, 'Look Both Ways: Studying Emotion in Ancient Greek', Critical Quarterly 50.4 (2008), 43-63; A. Chaniotis (ed.), Unveiling Emotions. Sources and Methods for the Study of Emotions in the Greek World (Stuttgart, 2012); A. Chaniotis and P. Ducrey (eds.), Unveiling Emotions II. Emotions in Greece and Rome. Texts, Images, Material Culture (Stuttgart, 2013); D. Cairns and L. Fulkerson (eds.), Emotions between Greece and Rome (London, 2015); D. Cairns, 'Mind, Body, and Metaphor in Ancient Greek Concepts of Emotion', in D. Boquet and P. Nagy (eds.), Histoire intellectuelle des emotions, de l'antiquité a nos jours, L'Atelier du Centre de Recherches Historiques 16 (2016), <https://doi.org/ 10.4000/acrh.7416>, accessed 16 November 2020; E. Sanders and M. Johncock (eds.), Emotion and Persuasion in Classical Antiquity (Stuttgart, 2016); A. Chaniotis, N. Kaltsas, and I. Mylonopoulos (eds.), A World of Emotions. Ancient Greece 700 BC-200 AD (New York, 2017); D. Cairns (ed.), A Cultural History of the Emotions in Antiquity (London, 2019).
} 
These will be the main lines of my approach: Medea's emotions recorded by herself; the symptoms of her emotions; the fluctuations of her emotions; and her emotions in the past as opposed to her present emotions. As mentioned above, the particularity of Medea's letter to Jason is that, although it is supposedly written at a given moment in her story, it includes both a retrospective account of past events and anticipations of things to come. Consequently, the emotions expressed by Medea are not just the emotions she experiences at the time of writing, but also her emotions in the past - both her past as an individual and her textual past, that is, her past as a literary heroine featuring in earlier texts, such as Euripides' Medea, Apollonius' Argonautica, and Ennius' Medea exul.

Medea sets the tone right from the start of her letter. She is bitter and remorseful for all that has happened and wishes she had died honourably before meeting Jason (Her. 12.3-6):

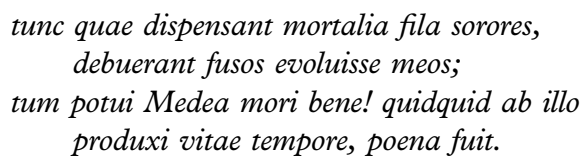

The Fates, who spin the thread of a mortal's life, should have ended mine and killed me then. I could have died well then. All my life since that time has been punishing.

Hence, what we are going to read are the personal thoughts of a woman who has regretted her actions, and experiences bitterness, remorse, and guilt. ${ }^{13}$ The review of her life so far is clearly negative. Medea pities herself and charges her letter with emotion, using a typical exclamatory phrase of sadness, ei mihi (12.7-12): ${ }^{14}$

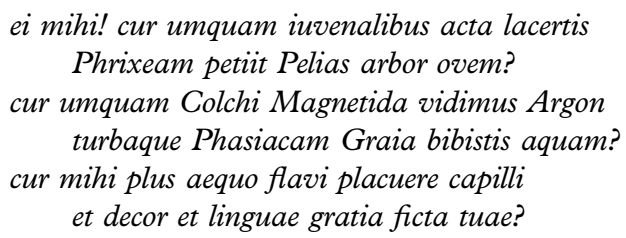

${ }^{13}$ On Medea's consciousness of her own guilt in Heroides 12 (lines 6, 109-16, 118-19, 129-32) see Davis (n. 7), 41-2.

${ }^{14}$ This phrase probably derives from the Homeric $\ddot{\omega} \mu$ or (Il. 1.414, 7.96; Od. 5.299, 13.200, etc.); it is used only in poetry, and is preferred by Latin poets in the place of vae. It is very common in elegy and of course in the Heroides $(2.106,3.14,5.60,9.45,11.114,12.9,13.48,16.339,17.92$, $17.248,20.109,21.110$, etc.), occupying this specific metrical position. See V. A. Tracy, 'The Authenticity of Heroides 16-21', Cf 66 (1971), 329. 
Oh, why did the Argo ever go in quest of the Golden Fleece, rowed by its young crew? Why did we Colchians ever set eyes on that ship and you Greeks drink from our river Phasis? Why did I find your blond hair and good looks and your charming, lying tongue all too attractive?

The three successive questions introduced with cur and spreading over three couplets pick up the famous beginning of Euripides' Medea (1-6): ${ }^{15}$

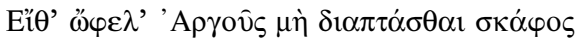

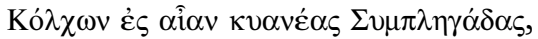

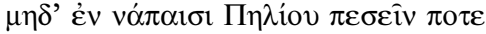

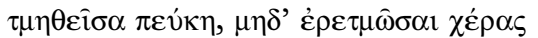

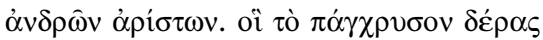

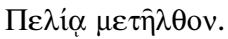

Oh how I wish that Argo's hull had never winged its way to the land of the Colchians, past the dark-blue Symplegades, I wish that pine trees had never been felled in Pelion's glens nor filled with oars the hands of those great men who at Pelias' command set off in quest of the golden fleece.

It is evident right from the start that sadness is going to dominate Medea's letter, though not exclusively. Medea also states that she will gain pleasure (voluptas) and joy (gaudium) from demonstrating Jason's ingratitude (12.21-2): est aliqua ingrato meritum exprobrare voluptas; / hac fruar, haec de te gaudia sola feram ('I'll take what pleasure there is in attacking the ingratitude of someone who's been helped - the only joy I'll get from you'). ${ }^{16}$ Exposing her ex-husband's evil character will soften her pain and give her the peculiar satisfaction of revenge. This is the single joy (gaudia sola) that Medea is now expecting to receive. This kind of vengeance, the moral deconstruction of Jason, clearly paves the way for the more drastic revenge that will take place in the future, after the completion of the letter.

Shortly before this declaration, Medea attacks Jason using the first in a series of angry, aggressive, and derogatory addresses: inmemor Aesonides ('thoughtless Jason'; 12.16). ${ }^{17}$ She sarcastically uses the epic patronymic Aesonides and highlights Jason's trademark features:

${ }^{15}$ Hinds (n. 1), 34; Davis (n. 7), 33.

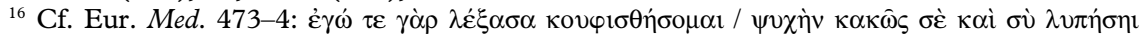
$\kappa \lambda \nu$ $\omega v$ ('For I will relieve my heart reviling you, and you will be stung by my words').

${ }^{17}$ She is about to throw many pejorative names at Jason which manifest her rage against him: sceleratus (19), ingratus ('ungrateful', 21), perfidus ('traitor', 37), infidus ('treacherous', 72), latro peregrinus ('pirate from overseas', 111), inprobus ('shameless', 204). 
oblivion, faithlessness, and ingratitude. Jason has forgotten (or wants to forget), whereas Medea remembers (or wants and needs to remember). Medea then presents a flashback, starting from the moment she first laid eyes on Jason in the palace of Aeëtes at Colchis (12.21-50). She recounts Jason's arrival and the dangerous missions that her father assigned to him. The emotion that clearly dominates this part of her letter, which deals with the past, is love. Medea openly confesses her love for Jason, a love at first sight which proved disastrous (12.31-6):

\author{
tunc ego te vidi, tunc coepi scire quid esses; \\ illa fuit mentis prima ruina meae. \\ et vidi et perii! nec notis ignibus arsi, ${ }^{18}$ \\ ardet ut ad magnos pinea taeda deos. \\ et formosus eras et me mea fata trahebant: \\ abstulerant oculi lumina nostra tui.
}

It was then that I saw you and found out what you were; that was the start of my mental collapse. I saw you and died, I burned with a fire new to me, like a pine-torch burning on an altar to mighty gods. You were handsome, I couldn't resist what was fated for me, and my eyes were ravished by yours.

Medea renders her attraction to Jason with the well-established metaphor of love as fire. What causes her love, before she and Jason even meet and talk in private, is his beauty (formosus eras) and her fate (me mea fata trahebant). ${ }^{19}$ What Medea also makes sure to stress is that love was unknown to her (nec notis ignibus arsi), since she had been uninitiated in such matters until then. This is a crucial part of Ovid's strategy, namely to depict her as the innocent and naïve victim of a treacherous and ruthless man. ${ }^{20}$ In lines $89-92$ Medea refers to the

${ }^{18}$ See Hinds (n. 1), 21-7, for a very interesting analysis of the rich intertextual correspondence of this line with Verg. Ecl. 8.41 (ut vidi, ut perii, ut me malus abstulit error, 'as I saw you, I was lost,

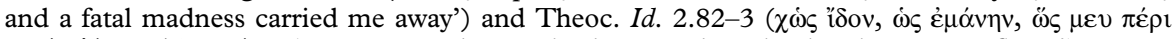

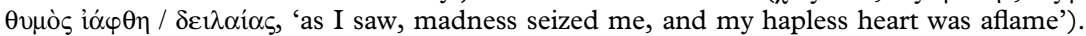

${ }^{19}$ Cf. Ov. Her. 6.51: sed me mala fata trahebant ('but an evil fate drew me on'), with Hinds (n. 1), 28-9.

${ }^{20}$ This image of Medea is compatible with her depiction in Apollonius' Argonautica. Davis (n. 7), 33: 'Medea plays the "simple girl" in Colchis, the murderous wife in Iolcus, the abandoned mother in Corinth, the poisonous stepmother in Athens and the potential filicide back in Colchis.' Jacobson (n. 6), 111-19, claims that the Medea of Ov. Her. 12 is more immoral and criminal that the Medea of Apollonius' Argonautica. According to F. Verducci, Ovid's Toyshop of the Heart. Epistulae Heroidum (Princeton, NJ, 1985), 68-71, in Her. 12 Euripides' mature and demonic Medea fuses with Apollonius' young and mild Medea. See also Vaiopoulos (n. 4), 136-7, 140. On the progressive transformation of Medea from innocent girl to wicked sorceress in Ov. Met. 7.1-424, see I. Gildenhard and A. Zissos (2013), 'The Transformations of Ovid's Medea 
effect of Jason's hypocritical entreaties (73-88), which were accompanied with false tears:

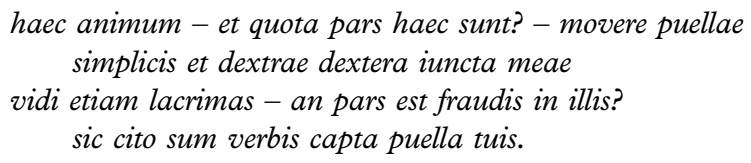

Your speech (and this is just a small part of it) and the clasping of my hand touched my naive, girlish heart. I also saw tears (they played their part in your deception); and I was just a girl, quickly taken in by your words.

Medea admits that she was captivated by Jason's charm and his manipulative words. In fact, Jason was able to perceive her emotions and exploit them for his own benefit. The fact that the inexperienced Medea could not hide her emotions, made her vulnerable to an experienced man such as Jason (12.37-8): perfide, sensisti! quis enim bene celat amorem? / eminet indicio prodita flamma suo ('You realized, you traitor. Who succeeds in hiding love? It flares up clearly, giving itself away').

Medea's instant love for Jason at Colchis causes her to be fearful for his safety. His life is in grave danger because of the missions Aeëtes has imposed on him. Medea records the grief of Jason and his companions upon hearing the words of her father (12.51): dixerat Aeetes: maesti consurgitis omnes) ('Aeetes had spoken: you all rise in gloom'), but also records her own anxiety about his fate (12.55-6): tristis abis. oculis abeuntem prosequor udis / et dixit tenui murmure lingua: 'vale!' ('You went off, despondent. I watched you go with tears in my eyes, and with a faint murmur I wished you well!'). Like a typical elegiac girl (puella) in love, ${ }^{21}$ Medea experiences classic love symptoms and spends sleepless nights, crying and agonizing about Jason's fate (12.57-8): ut positum tetigi thalamo male saucia lectum, / acta est per lacrimas nox mihi quanta fuit ('I went to bed in my room, badly wounded by love, and spent the whole night long crying'). ${ }^{22}$

In a very composed and calm manner, the Ovidian Medea of the dramatic present recalls and contemplates the troubled emotions she had

(Metamorphoses vii. 1-424)', in I. Gildenhard and A. Zissos (eds.), Transformative Change in Western Thought. A History of Metamorphosis from Homer to Hollywood (London, 2013), 95-6.

${ }^{21}$ See Davis (n. 7), 44.

${ }^{22}$ Cf. Ov. Her. 12.63-4: disiectamque comas aversaque in ora iacentem / invenit et lacrimis omnia plena meis ('and [my sister] found me lying face-down, with dishevelled hair, and everything wet with my tears'). 
experienced in the past, in Apollonius' Argonautica. Making an extraordinary self-referential comment, she refers to the past simultaneous existence within her of both love (amor) for Jason and fear (timor) for what was about to happen (12.61): hinc amor, hinc timor est - ipsum timor auget amorem ('I felt both love and fear, and the fear increased the love'). Most often in Ovid, and especially in the Heroides, the heroines face a classic dilemma between love and fear (amor and timor) or between love and shame (amor and pudor). Amor fights against timor or pudor each time a woman wants to help or follow the man she loves. However, in the case of Ovid's Medea, the fear (timor) she feels does not oppose her love for Jason, but instead fuels and magnifies it. While Jason is performing the deeds commissioned by Aeëtes, Medea watches pale with fear (12.97): ipsa ego, quae dederam medicamina, pallida sedi ('Even I, who'd given you the magic salve, sat there pale').

Medea's reminiscences of her past with Jason are thus dominated by love for him and fear for his fate. These emotions urge her to commit the first in a series of crimes in Jason's service, the murder and dismemberment of her brother, Absyrtus. Ovid's Medea declares her sincere repentance and is filled with sadness and remorse for what she has done. However, although she confesses her guilt, ${ }^{23}$ she suppresses the details of her abominable crime (12.113-16):

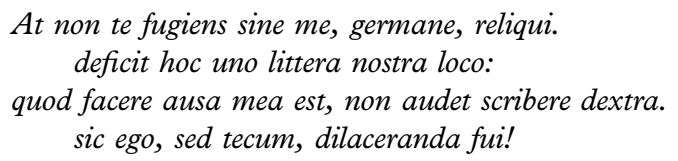

But I didn't leave you behind, my brother, when I fled (this is the only place where my pen falters). What I dared to do I don't dare to write down; I should have been hacked apart too, along with you!

After completing the narrative of past events in Colchis - her encounter with Jason, her decisive assistance for the accomplishment of his feats, their dramatic escape from Colchis, and their arrival in Greece - Medea dedicates the next section of her letter to more recent

${ }^{23}$ Euripides' Medea, too, admits to killing her brother, but she does not reveal any details (Med.

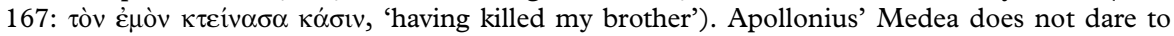

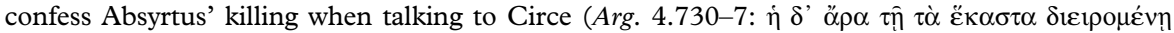

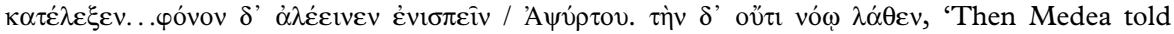
her all she asked. ..but of the murder of Absyrtus she was careful not to speak'). On the emotive language of Ov. Her. 12.109-16, see Davis (n. 7), 35-6. 
events: her divorce from Jason and his marriage to Creusa, the daughter of Creon, King of Corinth. This part of the letter is highly charged as well, but Medea's dominant emotions are different: she is now filled with pain, anger, and rage against Jason. ${ }^{24}$ She begins this section very aggressively: angry and sorrowful, she recalls her divorce from Jason (12.133-4): ausus es -o iusto desunt sua verba dolori! - / ausus es 'Aesonia' dicere 'cede domo!' ('You dared - I'm so angry (rightly angry) that the proper words fail me - you dared to say: "Leave my royal home!"'). It is really striking, however, that, despite Jason's ungratefulness and cruelty, Medea is still in love with him. In her own words, her love for Jason is always with her (12.135-6): iussa domo cessi natis comitata duobus / et, qui me sequitur semper, amore tui ('I left your home, as ordered, taking along our two sons and my love for you (which is always with me)').

Separation and desertion by Jason is not the only blow for Medea. The situation becomes even harder for her as Jason marries Creusa. In the most dramatic section of her Ovidian letter (12.137-58), Medea recounts Jason's wedding ceremony with Creusa, and records her reactions and the emotions of pain and sorrow that she experienced as an eyewitness. The description of the wedding is enlivened by the alternate use of the historical present (venit, micant, effundit, ruunt, clamant, inquit) and past tenses (pertimui, putabam, erat, erat, flebant, tegebant, vellet, erat, iuvabat, scirem, erat, constitit, planxi, fuere, suadebat, continui, clamarem, inicerem), an indication of Medea's troubled emotional state as she recalls this painful experience. ${ }^{25}$ As she herself states, upon hearing Jason's wedding ceremony - which she had no

\footnotetext{
${ }^{24}$ Davis (n. 7), 44: 'Medea... is a woman who is best remembered for her anger, an emotion that is characteristic of both epic ("anger" being the first word of the first epic) and tragedy (note the teacher's comment at Remedia 375: tragicos decet ira cothurnos, "anger suits tragic buskins").' Regarding Seneca's Medea, G. Guastella, 'Virgo, Coniunx, Mater: The Wrath of Seneca's Medea', ClAnt 20 (2001), 200, notes that, because of the divorce, Medea loses her identity and status as Jason's wife and is stripped off the meaning of everything that she did as a virgo in order to become the coniunx/mater. On anger in classical literature, see, among others, W. V. Harris, Restraining Rage. The Ideology of Anger Control in Classical Antiquity (Cambridge, MA, 2001); S. Braund and G. W. Most (eds.), Ancient Anger. Perspectives from Homer to Galen (Cambridge, 2003); K. Kalimtzis, Taming Anger. The Hellenic Approach to the Limitations of Reason (London, 2012).

${ }^{25}$ Ov. Her. 12.137-42: ut subito nostras Hymen cantatus ad aures / venit et accenso lampades igne micant / tibiaque effundit socialia carmina vobis, / at mihi funerea flebiliora tuba, / pertimui, nec adhuc tantum scelus esse putabam, / sed tamen in toto pectore frigus erat ('Suddenly I heard the words of a wedding-song and saw brightly gleaming torches, and a flute played the wedding-march for you two, a sound more mournful than a funeral dirge for me. I was terrified. I didn't yet believe such wickedness existed, but still my heart was all cold with fear').
} 
idea about - she is gripped by intense fear, which freezes her heart, a typical symptom of fear (12.141-2): pertimui, nec adhuc tantum scelus esse putabam, / sed tamen in toto pectore frigus erat ('I was terrified. I didn't yet believe such wickedness existed, but still my heart was all cold with fear'). To make things worse, while Medea is filled with sorrow (148: mens mea tristis erat), her own child is an eyewitness to his father's wedding (12.149-50): cum minor e pueris iussus studioque videndi / constitit ad geminae limina prima foris ('My youngest boy, either just by chance or because he was keen to see, stood at the front door'). With genuine childish excitement, Medea's little son describes Jason's wedding ceremony without realizing its dire consequences. Her narrative is heart-rending as she quotes her son's words upon seeing his father leading the wedding procession (151-2): 'hinc' mihi 'mater, abi! pompam pater', inquit, 'Iason / ducit et adiunctos aureus urget equos!' ('He said: "Mother, just come here! Father's leading a procession, dressed in gold and driving a chariot!"'). Medea's reaction to these words is wholly indicative of her emotional state (12.153-4): protinus abscissa planxi mea pectora veste / tuta nec a digitis ora fuere meis ('Immediately I ripped my clothes and beat my breasts and scratched my face in grief'). She bursts out into extreme lamentation, with all its established gestures: she tears off her clothing, she beats her chest, and she rips her cheeks with her fingers.

For a woman in the ancient world, mourning was a socially accepted means of articulating anger, and is totally in line with the elegiac character of the Heroides. Medea's mourning is the first step towards revenge. ${ }^{26}$ Anger, sadness, and despair overwhelm Medea and urge her to throw herself amid the procession and disrupt the wedding, claiming Jason for herself. Only at the last moment does she manage to hold back (12.155-8):

$$
\begin{aligned}
& \text { ire animus mediae suadebat in agmina turbae } \\
& \text { sertaque conpositis demere rapta comis. } \\
& \text { vix me continui, quin sic laniata capillos } \\
& \text { clamarem 'meus est!' iniceremque manus. }
\end{aligned}
$$

${ }^{26}$ Similarly, Oenone's sorrow at her abandonment by Paris is the first phase of her revenge: see A. N. Michalopoulos, 'A Phrygian Tale of Love and Revenge: Oenone Paridi (Ovid Heroides 5)', in L. Dawson and F. McHardy (eds.), Revenge and Gender in Classical, Medieval and Renaissance Literature (Edinburgh, 2018), 239-50. On revenge in classical literature, see also, among others, A. P. Burnett, Revenge in Attic and Later Tragedy (Berkeley, CA, 1998); F. McHardy, Revenge in Athenian Culture (London, 2008). 
I felt an urge to plunge into the crowd and tear the garlands from their neatly combed hair. I scarcely restrained myself from tearing my hair, shouting 'He's mine!' and grabbing hold of you.

The stunning event of Jason's new wedding, which Medea is watching live, so to speak, is the last straw, which mobilizes her to conceive a plan for revenge, especially when she thinks that her downfall will bring joy to those she had abandoned (Aeëtes, the Colchians, Absyrtus) (12.159-60): laese pater, gaude! Colchi gaudete relicti! / inferias umbrae fratris habete mei ('I hope this delights the father I wronged, the Colchians I abandoned; let my brother's ghost accept this offering to him'). Medea's wounded pride turns into rage and spite. What makes things even worse for her is realizing that her magic powers can no longer help her and that she is unable to quench the flames of her love for Jason (12.163-8): ${ }^{27}$

$$
\begin{aligned}
& \text { serpentes igitur potui taurosque furentes, } \\
& \text { unum non potui perdomuisse virum. } \\
& \text { quaeque feros pepuli doctis medicatibus ignes, } \\
& \text { non valeo flammas effugere ipsa meas. } \\
& \text { ipsi me cantus herbaeque artesque relinquunt; } \\
& \text { nil dea, nil Hecates sacra potentis agunt. }
\end{aligned}
$$

So, I managed to subjugate serpents and mad bulls, but I could not subjugate this single man. I repulsed fierce flames with my magic expertise, but I can't escape the fire of love myself. My very skills and spells and herbs are deserting me; my powerful Hecate and her rites are quite useless.

Because of the emotional storm raging in her soul, Medea abhors the light of day and spends sleepless nights, typical symptoms of suffering. Her inability to sleep ironically comes in sharp contrast with her own feat of putting to sleep the sleepless dragon guard of the golden fleece (12.169-72):

\footnotetext{
non mihi grata dies; noctes vigilantur amarae

et tener a misero pectore somnus abit.

quae me non possum, potui sopire draconem.

utilior cuivis quam mihi cura mea est.
}

I loathe the daytime, my nights are wakeful and hateful, soft sleep abandons me in my misery. I can put to sleep a serpent, but not myself; everyone profits from my industriousness more than me. 
Her rage is spurred on even more by the thought that she may have become the laughing stock in Jason's private talks with his new wife (12.175-9):

\author{
forsitan et, stultae dum te iactare maritae \\ quaeris et iniustis auribus apta loqui, \\ in faciem moresque meos nova crimina fingas. \\ rideat et vitiis laeta sit illa meis! \\ rideat et Tyrio iaceat sublimis in ostro.
}

Perhaps too, when you're trying to show off to your stupid wife and say things my enemy would like to hear, you come up with new criticisms of my looks and my foreign ways. Let her laugh and take pleasure in my faults! Let her laugh, lying on her purple couch, exalted.

Medea's emotions at Jason's betrayal and abandonment - sadness, despair, and anger - set things in motion and push her to the point of no return. The tone of her letter becomes extremely menacing. She threatens Creusa with revenge and emphatically states that no enemy of hers will be left unpunished (12.180-2):

flebit et ardores vincet adusta meos.

dum ferrum flammaeque aderunt sucusque veneni, hostis Medeae nullus inultus erit.

She will weep, burnt even worse than me. So long as I have a sword and fire and magic potions, no enemy of Medea will escape vengeance.

However, before proceeding to carry out her vengeful plan, Medea resorts to a final entreaty to Jason, urging him to return to her and their children. She invokes the gods and reminds Jason of his promises and her good services to him (12.183-206). While one perhaps would expect the letter to end with this supplication to Jason, she suddenly changes her mood once again, and moves from appeals for compassion to rage and threats. This abrupt transition is entirely indicative of her troubled psychological state (12.207-12):

\footnotetext{
...sed quid praedicere poenam

attinet? ingentis parturit ira minas.

quo feret ira sequar. facti fortasse pigebit;

et piget infido consuluisse viro.

viderit ista deus, qui nunc mea pectora versat.

nescio quid certe mens mea maius agit.
} 
...but why tell you your punishment in advance? My rage will give birth to massive menace. I'll go where rage takes me. I may regret what I do, but I also regret looking out for my unfaithful husband. I'll leave that to the god who now has my thoughts in a turmoil. My mind is definitely devising something drastic.

Medea clearly foreshadows her imminent revenge, to which she is driven by her feelings of desertion and rage (quo feret ira sequar). ${ }^{28}$ She is fully conscious of her emotions and she openly states that her actions are dictated by anger, and that she is under the control of a certain god (viderit ista deus, qui nunc mea pectora versat), whom she does not name (Amor perhaps?). The last line of the letter, nescio quid certe mens mea maius agit, signals that something bad is about to happen. In a remarkably menacing tone, Medea suggests that the plan for her cruel revenge against Jason and Creusa has already started to form in her mind. What comes next is what unfolds in Euripides' Medea; Medea's Ovidian letter ends at the point where the action in Euripides begins. The term maius carries metaliterary suggestiveness: it refers to tragedy, a genre higher than the humble elegy. After finishing her Ovidian letter, this elegiac Medea will enter the tragic stage and become the notorious infanticide. ${ }^{29}$

To conclude: the study of Medea's letter to Jason (Ov. Her. 12) from the point of view of emotions is conducted here for the first time. Although it is not lacking a certain logic of argumentation, the letter is fraught with emotions which succeed one another at a quick pace from beginning to end. Ovid's Medea, a letter-writer and not a character of epic or tragedy, appears as human as she can be. She is a character shaped by a wide range of emotions, which span her entire literary career. Ovid offers his Medea the opportunity to present her own truth,

\footnotetext{
${ }^{28}$ Davis (n. 7), 46: 'But if Medea's past belongs to epic, her future lies with tragedy. While it is true that anger is an epic emotion, anger is also the passion which defines Medea on the tragic stage. Giving advice for aspiring tragedians, Horace declares in his Art of Poetry that Medea must be "fierce and invincible" (ferox inuictaque, 123). Hence it is not surprising that Euripides

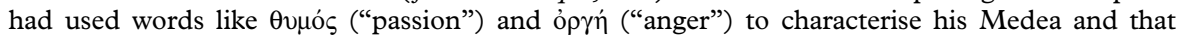
Seneca focuses upon her ira, her "anger". At the end of Heroides 12 the Ovidian Medea also speaks of ira: ingentis parturit ira minas. / quo feret ira sequar ('Anger gives birth to huge threats. Where anger takes me I will follow', 208f.).'

${ }^{29}$ See Spoth (n. 1), 203-4; Hinds (n. 1), 39-43; A. Barchiesi, 'Future Reflexive: Two Modes of Allusion and Ovid's Heroides', HSPh 95 (1993), 344; L. Landolfi, 'Nescio quid certe mens mea maius agit (Her. XII, 212): Medea fra analessi e prolessi letteraria', Pan 15-16 (1998), 57-89; L. Fulkerson, The Ovidian Heroine as Author. Reading, Writing, and Community in the Heroides (Cambridge, 2009), 86; Davis (n. 7), 34, 46. For the gradual transformation of the elegiac Medea into the tragic Medea, see C. M. Ugartemendia, 'Sed tibi servatus gloria maior ero: Medeia e a fronteira entre o elegíaco e o trágico em Heroides XII', Phaine. Revista de Estudos Sobre a Antiguidade 3 (2017), 33-42.
} 
her own interpretation of things. Capitalizing upon the particular conventions and features of epistolography, she presents her thoughts and emotions and has the opportunity to speak in the first person about how she feels. Her emotions do not need to be deduced from her actions; she openly writes about them herself through the mediation of her creator, Ovid, who elaborates on Medea's changing generic identity within literary tradition and engages with his literary predecessors (Euripides, Apollonius, and Ennius).

The Ovidian Medea portrays herself as the innocent and naïve victim (33: nec notis ignibus arsi, 'I burned with a fire new to me'; 89-90: puella simplex, 'simple girl') of a cunning and ruthless man, who first exploited her to achieve his goals and then abandoned her for the sake of a richer and politically more powerful new wife. These emotions are the motivating force for Medea: her instant love for Jason at Colchis causes her to fear for his fate and pushes her to help him carry out the deadly trials set by Aeëtes. Out of love for Jason, she sacrifices her brother, Absyrtus; she feels guilty and remorseful for her deed, but all too late: brotherly love succumbs to romantic love. After that, her betrayal and abandonment by Jason causes her suffering, pain, and sorrow, as well as fear for her own fate. These emotions quickly turn into anger and urge her to act against Jason and his new wife. Her anger and pain become a desire to inflict pain in retaliation. Medea will eventually get even with her treacherous ex-husband, after first undergoing a phase of lamentation, anger, and frustration. As a mourner, Medea is a potential revenger; although initially a victim, she will soon move from lamentation to revenge and make Jason pay for his betrayal.

ANDREAS N. MICHALOPOULOS

National and Kapodistrian University of Athens, Greece amichalop@phil.uoa.gr 